\title{
Eritema nodoso e infecção pelo vírus da hepatite $\mathrm{C}^{*}$ Erythema nodosum and infection by hepatitis $C$ virus*
}

\author{
Thelma Skare \\ Rafael Bonan ${ }^{2}$
}

$\mathrm{O}$ vírus da hepatite $\mathrm{C}$ é um RNA vírus que causa hepatite crônica em $75 \%$ dos indivíduos infectados.' Tanto a infecção aguda como a crônica podem ser assintomáticas ou cursar apenas com sintomas leves e inespecíficos, de tal maneira que a doença é, muitas vezes, detectada tardiamente, quando os medicamentos usados para tratamento têm sua eficácia reduzida. ${ }^{2}$

O diagnóstico precoce dessa doença pode ser facilitado se o médico estiver apto para reconhecer suas manifestações extra-hepáticas, como, por exemplo, as dermatológicas. Têm sido descritos casos de vasculites por crioglobulinemia, ${ }^{2}$ porfiria cutânea tardia, ${ }^{1,2}$ líquen plano, ${ }^{1,2}$ vitiligo, ${ }^{2}$ poliarterite nodosa ${ }^{1}$ e prurido generalizado' associados à infecção pelo vírus $\mathrm{C}$.

Os autores apresentam um caso de infecção pelo vírus $\mathrm{C}$ numa mulher grávida, cujo diagnóstico foi feito pela presença de eritema nodoso.

Trata-se de paciente de 28 anos, com história de nódulos avermelhados e dolorosos nos membros inferiores que apareciam de maneira intermitente há dois anos. Havia feito uso de glicocorticóide, por pouco tempo, na tentativa de solucionar as queixas, sem ajuda. No momento da consulta a paciente não usava medicamentos, salvo alguns comprimidos de paracetamol esporadicamente. Negava sintomatologia articular, fotossensibilidade ou fenômenos vasomotores. Tinha história de alopecia leve e de úlceras orais. Ex-tabagista, era gestante de sete meses, sendo aquela sua terceira gestação. Não tinha tido sintomas semelhantes nas gestações anteriores. Ao exame físico a paciente apresentava sinais vitais normais; precórdio com bulhas rítmicas e normofonéticas; pulmões limpos. Abdômen com aumento uterino compatível com 28 semanas de gravidez e sem outras visceromegalias. Na pele da região pré-tibial existiam lesões compatíveis com eritema nodoso bilateralmente (Figura 1).

A biópsia da lesão cutânea mostrou presença de áreas nodulares de infiltração inflamatória com histiócitos, linfócitos e raros neutrófilos associados a áreas de necrose

\begin{abstract}
Hepatitis $C$ virus is an RNA virus that causes chronic hepatitis in $75 \%$ of infected individuals. ${ }^{l}$ As much the acute infection as the chronic may be asymptomatic or may course with only slight and unspecific symptoms. Because of this the disease is often detected quite late, when the medicines used for its treatment have a reduced effectiveness. ${ }^{2}$

An early diagnosis of this disease can be facilitated if the doctor is alert in recognizing the symptoms that are not hepatic, such as those that are dermatological in nature. The following have been reported as being associated with the infection by hepatitis $C$ virus: vasculitis due to cryoglobulinemia, ${ }^{2}$ late cutaneous porphyria, ${ }^{1,2}$ lichen planus, ${ }^{1,2}$ vitiligo, ${ }^{2}$ polyarteritis nodosa $a^{l}$ and generalized pruritus. ${ }^{l}$

In this paper a case is presented involving infection by hepatitis $C$ virus in a 28-year-old pregnant woman and the diagnosis was confirmed by the presence of erythema nodosum.
\end{abstract}

This patient had a history of red and painful nodules in the lower limbs. They had begun appearing intermittently two years previously. She had used a glucocorticoid for a short while, in an unsuccessful attempt to resolve the problem. At the time of the consultation the patient was not using any medication, except for the sporadic use of some paracetamol tablets. She denied having any articular symptomatology, photosensitivity or vasomotor phenomena. She had a history of mild alopecia and oral ulcers. A former-smoker, she was seven months pregnant, this being her third pregnancy. She had not had similar symptoms in the previous pregnancies. Physical exam showed normal vital signs; precordial auscultation showed normal rhythmic sounds, indicating clean lungs. The abdomen had a uterine increase compatible with 28 weeks of pregnancy and without other visceromegaly. Bilaterally in the skin of the pre-tibial area she presented lesions compatible with those of erythema nodosum (Figure 1).

Biopsy of a cutaneous lesion revealed the presence of nodular areas with an inflammatory infiltration of histiocytes, lymphocytes and a few neutrophiles. This was associated with

\footnotetext{
Recebido em 29.04.2002. / Received in April, 29 of 2002.

Aprovado pelo Conselho Consultivo e aceito para publicação em 13.06.2003. / Approved by the Consultive Council and accepted for publication in June, $13^{\text {th }}$ of 2003.

* Trabalho realizado no Serviço de Reumatologia do Hospital Universitário Evangélico de Curitiba- Paraná. / Work done at Reumatology Service of "Hospital Universitário Evangélico de Curitiba- Paraná".

Professora Assistente de Reumatologia do Curso de Medicina da Faculdade Evangélica de Medicina do PR (FEPAR). / Assistant Professor of Rheumatology, Faculdade Evangelica de Medicina do PR (FEPAR).

${ }^{2}$ Acadêmico do $6^{\circ}$ ano - FEPAR. / Sixth year medical student - FEPAR.

○2004 by Anais Brasileiros de Dermatologia
} 
Figura 1: Eritema nodoso na região tibial.

na derme reticular e tecido gorduroso; pesquisa de BAAR foi negativa.

A investigação laboratorial mostrou: células LE, fator reumatóide, VDRL e PPD negativos, FAN positivo em título baixo (1/80). Pesquisas de auto-anticorpos, como anti-

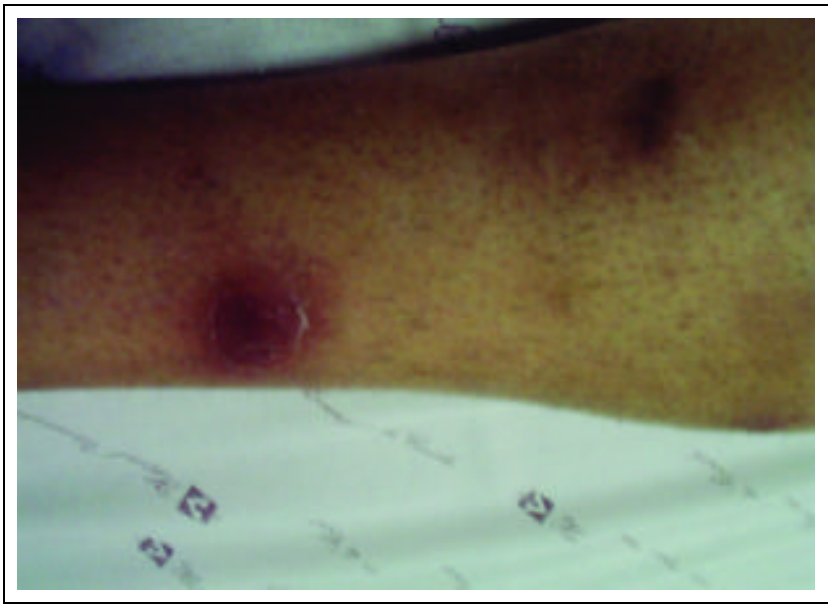

Figure 1: Erythema

nodosum in

tibial region.

Sm, anti-Ro/SSA, anti-La/SSB, anti-RNP, e crioglobulinas foram negativas. Dosagem de antiestreptolisina $\mathrm{O}$ foi normal; RX de tórax foi protelado por causa da gravidez. Provas de função hepática mostraram SGOT (transaminase oxalacética) de 118U/L (normal até 30U/L) e SGPT (transaminase pirúvica) de 102U/L (normal até 20U/L). A sorologia para HVC foi positiva, e essa infecção foi confirmada pela PCR. (teste da reação em cadeia pela polimerase) qualitativa. Genotipagem mostrou tratar-se do subtipo 3a.

Em virtude da positividade para hepatite $\mathrm{C}$, programou-se o parto via cesárea. Logo após o nascimento da criança, a paciente foi encaminhada para biópsia hepática e uso de ribavirine e interferon em outro serviço. Mediante contato telefônico, feito oito meses após o encaminhamento para biópsia e tratamento, a paciente informou estar passado bem, sem recidiva das lesões cutâneas até o momento.

O eritema nodoso é uma forma de expressão de hipersensibilidade mediada por células que se manifesta clinicamente pelo aparecimento de nódulos subcutâneos, dolorosos, situados mais comumente nas superfícies extensoras das pernas e que podem estar associados a febre, artralgias ou artrites e linfadenopatia. ${ }^{3}$

Várias doenças podem desencadear seu aparecimento. Entre elas estão as infecções, uso de medicamentos, sarcoidose, doença de Crohn e linfomas. A maior ou menor prevalência de uma ou outra causa depende da população estudada, uma vez que elas variam conforme a localização regional. ${ }^{4}$

A gravidez tem sido implicada em casos de eritema nodoso, ${ }^{3}$ e, no caso descrito, existia a possibilidade de que a mesma estivesse envolvida no processo etiológico. Entretanto, a paciente vinha tendo surtos recorrentes há dois anos, quadro iniciado quando a mesma não estava grávida.

A infecção pelo vírus da hepatite $\mathrm{C}$ como causa de eritema nodoso já foi identificada anteriormente, ${ }^{3,5,6}$ embora essa não seja associação freqüentemente reconhecida. $\mathrm{O}$ caso apresentado, ainda que não possa ser implicado diretamente na etiopatogenia do processo, permitiu não só o diagas anti-Sm, anti-Ro/SSA, anti-La/SSB, anti-RNP, and cryoglobulins were negative. The dosage of Antistreptolysin-O was normal. Chest X-ray test was postponed in view of the pregnancy. Testing for hepatic function showed SGOT (serum glutamic-oxaloacetic transaminase) at 118U/L (normal is up to 30U/L) and SGPT (serum glutamic-pyruvic transaminase) at 102U/L (normal is up to 20U/L). Serology for HCV was positive, and this infection was confirmed by PCR (polymerase chain reaction). Placement by genotyping was subtype $3 a$.

Because of the positivity for hepatitis $C$, delivery by cesarean section was programmed. Soon after the child's birth, the patient was referred to another service for hepatic biopsy and where she was treated with ribavirin and interferon. By telephone contact eight months after the biopsy and treatment, the patient affirmed that she was feeling well, with no further recurrence of the cutaneous lesions to date.

Erythema nodosum is a form of hypersensitivity expression mediated by cells that are manifested clinically by the onset of subcutaneous nodules. These are painful and located most commonly in the extensor surfaces of the legs. They may be accompanied by fever, arthralgia or arthritides and lymphadenopathy. ${ }^{3}$

Several diseases can trigger their appearance, including infections, sarcoidosis, Crohn's disease, lymphomas and even the use of certain medications. The greater or lesser prevalence of one or another cause of this disease depends on the population being studied, since the causes tend to vary from region to region. ${ }^{4}$

Pregnancy has been implicated in cases of erythema nodosum,,$^{3}$ and, in the described case, there existed the possibility that the pregnancy itself was involved in the etiological process. However, this patient had been suffering recurrent outbreaks for two years, beginning at a time when she was not pregnant.

Infection by hepatitis $C$ virus as a cause of erythema nodosum has already been reported, ${ }^{3,5,6}$ even so, this association is not frequently recognized. Although in the case presented here the fact that hepatitis cannot be implicated directly in the etiopathology of the process, the presence of erythema nodosum enabled a diagnosis of hepatic disease 
nóstico da doença hepática e instituição precoce de tratamento, como, ao se programar cesárea, diminuir os riscos de contaminação da criança pela via vertical.

\section{REFERÊNCIAS / REFERENCES}

1. Bonkovsky LH, Mehta S. Hepatitis C: a review and update. J Am Acad Dermatol 2001;44:159-79.

2. Schwabwer MJ, Zlotogorski A. Dermatologic manifestations of hepatitis C infection. Int J Dermatol 1997;36:251-4.

3. Dixey JJ. Erythema nodosum In Klippel J, DieppePA. Rheumatology 2nd Ed, Ed Mosby, London,1998; Sec 5; 25. 1-4

4. García-Porrua C, González-Gay MA, Vásquez-Caruncho M et al. Erythema nodosum, Artrithis Rheum 2000;43(3):584-92.

5. Domingo P, Rios J, Martinez E, Casas F. Erythema nodosum and hepatitis C (letter). Lancet 1990; 336:1377.

6. Terver MNG, Modiano P, Gogolewski S, Gaucher P, Schmutzb and early institution of treatment. Furthermore, this diagnosis indicated the need for cesarean section to reduce the risks of vertical contamination of the child during delivery.

JL. Erythème nouex rélélateur dúne hépatite $\mathrm{C}$ chronique active (letter). Presse Medicale 1995;24 (26):1221.

ENDEREÇO PARA CORRESPONDÊNCIA: / MAILING ADDRESS:

Thelma L Skare

João Alencar Guimarães, 796

80310-420 Curitiba PR

Tel./fax: (41) 274-1659 / 240-5082

E-mail:tskare@onda.com.br 